EnJourMe (English Journal of Merdeka): Culture, Language, and Teaching of English

Journal homepage: http://jurnal.unmer.ac.id/index.php/enjourme/index

\title{
Assessing an effective collaboration in higher education: A study of students' experiences and challenges on group collaboration
}

\author{
${ }^{1}$ Malikhatul Lailiyah, ${ }^{2}$ Lian Agustina Setiyaningsih, ${ }^{3}$ Prilla Lukis Wediyantoro, \\ ${ }^{4}$ Karlina Karadila Yustisia \\ 1,3,4D3 English Program, Faculty of Politics and Social Science, Universitas Merdeka Malang, Jl. Terusan Raya Dieng No. 62-63, \\ 65146, Malang, Indonesia \\ ${ }^{2}$ Department of Communication Science, Faculty of Politics and Social Science, Universitas Merdeka Malang, Jl. Terusan Raya \\ Dieng No. 62-63, 65146, Malang, Indonesia \\ Corresponding author: lian.agustina@unmer.ac.id
}

\section{ARTICLE INFO}

Article history:

Received 16 December 2021

Accepted 22 December 2021

Available online 30 December 2021

\section{Keywords:}

Collaboration, English as a

Foreign Language, social media

DOI: 10.26905/enjourme.v6i2.6971

How to cite this article (APA Style):

Lailiyah, L., Setiyaningsih, L.A., Wediyantoro, P.L., \& Yustisia, K.K. (2021). Assessing an effective collaboration in higher education: A study of students' experiences and challenges on group collaboration. EnJourMe (English Journal of Merdeka) : Culture, Language, and Teaching of English, 6(2) 152162. doi: https://doi.org/10. 26905/enjourme.v6i2.691

\section{ABSTRACT}

Studies emphasize that collaboration remains an essential part of learning and working in the 21st century. This study seeks to report on the group collaboration of higher education students. Using Explanatory sequential mixed method design, this study tried to discuss the students' experiences and challenges on group collaboration environment in the online learning cases. Adopting Razmerita and Kirchner's (2014) questionnaire, 287 students involved in this study. The result indicated that overall students performed positive perception on group collaboration. In addition, to have deep analysis, 15 students were interviewed. This study contributes to an understanding of how students perceived collaboration and how they explain the obstacles recognized in their classes.

(C)2021 The Authors. Published by University of Merdeka Malang This is an open access article distributed under the CC BY-NC-ND 4.0 (https://creativecommons.org/licenses/by-nc-nd/4.0/)

\section{Introduction}

The sudden outbreak of the Covid-19 virus has forced schools and universities to remain closed temporarily. To deal with this challenging situation, an emergency online learning has been proposed. The urgent need for saving the community is the main concern. During this situation, it is 
essential to not only develop an innovative learning approach to maintain the effective virtual interaction between teacher and students, but also to provide a solution on how can the teacher motivate the learners (Oh et al., 2020). Thus, to encourage students' motivation, teacher should create circumstances that enforce and influence students to engage in the learning activity (Nehme, 2010). Hence, with the rapid development of the use of technological tools for educational platforms, educators seek and explore many platforms to create a diverse learning experience for their students.

Many studies emphasize that collaboration remains to be essential for both educational and industrial sector in the 21st century (for example Bedir, 2019; Rotherham \& Willingham, 2010; Soule \& Warrick, 2015). The literature on modern pedagogy emphasizes that student-centred methods needed to take into account in which it should be based on collaboration and peer interaction connected to active learning that promote students' critical thinking (Lailiyah \& Wediyantoro, 2021).

An author defined collaboration as "mutual engagement of participants in a coordinated effort to solve a problem together" (Lai, 2011). Thus, an effective collaborative system should be able to understand and interpret group conversations, and can actively support participants in their purposes. Monitoring, understanding, and promoting collaborative learning activities begin with the understanding of behaviours that characterize effective collaborative learning interactions (Bedwell et al., 2012). Scholars of organizational behaviour, sociology, and anthropology regard collaboration as a process involving the interaction between social units, including people and organization (Longoria, 2005). In short, collaboration addresses the fact that it is not only occur outside of individuals or teams, but also across analysis levels, and involves any combination of social entities.

Many studies mentioned that the concept of collaboration is also related to a behaviouroriented focus on a particular goal (see Gallant et al., 2002; Henneman et al., 1995). Thus, a collabora-tive process can only be performed if the associated entities share at least one jointly agreed or com-monly defined goal to some extent. Clearly, engaging in the mutual purpose is the most demanding facet in collaborating with group and this mutual purpose is reason for two or more individuals to work together.

Collaborative learning is a teaching style in which students cooperate in small groups to solve a common task, and it has been shown to improve learner performance when classmates discuss an issue and offer viable solutions (Razmerita \& Kirchner, 2014). One study mentioned that a productive group, a familiar or close friends group member, and teacher support all have a significant impact on teamwork satisfaction. According to students, clear and frequent communication within the group member, the use of interactive software, and synchronous meetings were essential elements to fascinate group work (Tseng et al., 2009).

Vygotsky (1962) argues that students' knowledge construction is a product of social interaction, interpretation and understanding. The basic idea of social constructivism is that knowledge building is a social process that takes place through connections and collaboration with others. Therefore, in a constructivist learning approach, the learner is no longer a simple passive knowledge receiver. He is inspired to play an important role in building knowledge (Adams, 2006; Hein, 1991; Mondahl \& Razmerita, 2014).

To add more, peer interaction, according to Vygotsky, is an important means of facilitating individual cognitive growth and information acquisition. Vygosky's theory assumes that individuals 
Assessing an effective collaboration in higher education: A study of students' experiences and challenges on group collaboration Malikhatul Lailiyah, Lian Agustina Setiyaningsih, Prilla Lukis Wediyantoro, Karlina Karadila Yustisia

can master what they could not achieve before the collaboration because of their participation in collaborative activities. To put it another way, collaboration is more of a societal process for creating new information and cognitive progress than an individual endeavor.

Meanwhile, the benefits of collaborative exchange have been explained by the idea that peer interaction identifies gaps in knowledge, stimulates knowledge elaboration, and thus contributes to individual cognitive gains (Van Boxtel et al., 2000). Collaboration can be a powerful tools for facilitating the development of skills such as coordination, communication, dispute resolution, decision making, and negotiation (Lai, 2011). Besides, research also mentions that online collaboration or ecollaboration learning positively affects students' performance in a problem-solving group activity (see Tseng et al., 2009). In the relation between the use of social media and collaboration, many studies reported that the utilization of social media in learning supports collaboration and collaborative work (such as Al-Rahmi \& Zeki, 2017; Mondahl \& Razmerita, 2014; Razmerita \& Kirchner, 2014).

Previous study mentioned that students encounter several problem during collaboration (such as Van Boxtel et al., 2000). Head (2003) mentioned that forming "community of practice" is one of the effective ways to support students' collaboration. Thus, it is essential for lectures or faculties to provide this collaborative method. One of the famous Indonesian Ministry of Education and Culture program is Merdeka Belajar, Kampus Merdeka (Freedom Learning, Freedom University) or MBKM. This program aims to encourage students to master certain competencies. Student exchange programs, internships, research assistantships, humanitarian or social service projects, and other programs can be used to implement the MBKM curriculum both inside and outside the study program. MBKM is a learning innovation for students to be able to develop their potential. So that it is expected to produce creative and innovative students. In addition, this program is also expected to produce university graduates who have skills according to work needs so that they can reduce unemployment by synchronizing education and experience in the world of work and industry (Arifin $\&$ Muslim, 2020; Krishnapatria, 2021). So that joined this program can be beneficial for students.

In relation to this, research on e-collaborative applications has investigated the challenges perceived by only one participant, however, only few study discussed on investigating an effective collaboration. In order to solve these problems, the purpose of this study is to supplement the previous work by investigating various obstacles that may hinder the collaboration process and the possible antecedents that may lead to the identified obstacles from students' perspectives. In addition, we also discussed it in relation to the possible programs, such as MBKM, to propose students' engagement in any collaborative experience. This is important because understanding possible causes of ineffective collaboration can help the policymakers to promote more successful and enjoyable collaboration for students. In doing so, the following research questions were addressed:

1) How do students' perceptions relate to effective collaboration in online learning setting?

2) What are the roles of students' learning experiences outside the classroom, such as MBKM program, to promote students' collaboration? 
EnJourMe (English Journal of Merdeka): Culture, Language, and Teaching of

English Vol. 6, No. 2, Desember 2021, pp. 152-162

\section{Method}

To uncover students' experiences and challenges they perceived during the process of collaboration with groups, the study used Explanatory sequential mixed method design, in which the researchers to first experiment with quantitative data and analysis the result, then build a plan based on the result for the qualitative second phase (Creswell \& Creswell, 2017). The quantitative phase, the data were collected through close-ended questionnaire. Meanwhile, to shed some light on the quantitative findings, an open-ended questionnaire and interviews were employed.

Ethical approval was obtained prior to a study to collect anonymous participant data from Malang's private university instructors and college students. An overview of the data collection objectives is provided so that teachers and students participants could understand the underlying purpose of the survey. All participants voluntarily participated in surveys and interviews.

\subsection{Participants}

Two hundred eighty-seven students of Faculty of Social Sciences and Politics (ISIP), Merdeka University of Malang, aged 18-24 (66.9\% females and 33.1\% males) completed the online survey about their experiences on collaborative activity in a class. The first section of the questionnaire included participants' demographic information (see Table 1).

Table 1. Demographic information of participants

\begin{tabular}{lllr}
\hline Participants & Variable & Sub-variable & The respondents (\%) \\
\hline Students & Gender & Male & $95(33.1 \%)$ \\
& Female & $192(66.9 \%)$ \\
& Age (years) & 18 & $14(4.9 \%)$ \\
& 19 & $61(21.2 \%)$ \\
& 20 & $78(27.2 \%)$ \\
& 21 & $42(14.6 \%)$ \\
& 22 & $45(15.7 \%)$ \\
& 23 & $29(10.1 \%)$ \\
& Year level & $18(6.3 \%)$ \\
& & $126(43.9 \%)$ \\
& Sophomore & $97(33.8 \%)$ \\
& Junior & $64(22.3 \%)$ \\
\hline
\end{tabular}

\subsection{Data collection and the instruments}

In this study, to answer the first research question, the questionnaire used is developed by Razmerita and Kirchner (2014) adapted to fit the context in line with the university students' perspective on collaboration in learning environment. The questionnaire comprised ten Likert scale ranging from 1 (strongly disagree) to 5 (strongly agree) which explored different aspect of collaboration including students' understanding and satisfaction on group collaboration. This questionnaire also included one open-ended questions, seeking students' general perspective of learning through collaboration in group. To gather the data, an online survey was distributed. A brief overview of the 
Assessing an effective collaboration in higher education: A study of students' experiences and challenges on group collaboration Malikhatul Lailiyah, Lian Agustina Setiyaningsih, Prilla Lukis Wediyantoro, Karlina Karadila Yustisia

purpose of data collection is provided so that participants could understand the underlying purpose of the survey. Further, based on initial data analysis of the quantitative data, then semi-structured interview was conducted to have better understanding on the result of the survey. Fifteen students were selected using purposeful sampling and interviewed to follow up on the quantitative result. The interview was completed as one-on-one interview, ranging from 15-60 minutes of each participant.

Meanwhile, to gather the data for the second research question, an analysis of the implementation MBKM program in Merdeka University of Malang and its relation to collaborative learning was proposed. To be specific, only the data from the survey developed by Directorate General of Research and Technology under MBKM policy research program and interview of Faculty of ISIP students to be discussed in this study.

\subsection{Data analysis}

To provide a general depiction of participants' perspective on collaboration in group, the Mean and Standard Deviation are reported to show the general picture. In addition, ÿpa descriptive statistical analysis was conducted on the Likert- style data using SPSS 23. Meanwhile, the data from openended questions an interview were then imported to NVivo 12 Software for coding purposes. The first author posted the open-ended questionnaire data and uploaded it to the NVivo12 . Next, guided by keyword, the transcript then analysed thematically, as suggested by Braun and Clarke (2006). Results and interpretations were drawn from the data and reviewed by other member of the research team to allow for a broader discussion of the results.

Meanwhile, qualitative analysis of both the open-ended questions and interview data was integrated with the quantitative findings in the Results section. Qualitative data supports insights from quantitative results by providing detailed discussions and stories behind the numbers. The integration of results enriched the quantitative data by providing support and detailed information, examples, explanations, and discussions related to collaboration. Finally, the evaluation of the implementation of MBKM program and its relation to the collaboration skills will be discussed to answer the second research question.

\section{Results and discussion}

\subsection{Result}

The presentation of the results of this study consists of an order of study methods. The results of the Likert-style survey will be reported prior to the results of open questions and interviews

\section{Likert-style questions}

To elaborate the result of the study, the descriptive statistics, mean and standard deviation, are reported. In addition, we also calculated the proportion of each item. Table 2 shows the means, standard deviations, and proportions in each scale. 
EnJourMe (English Journal of Merdeka): Culture, Language, and Teaching of

English Vol. 6, No. 2, Desember 2021, pp. 152-162

Table 2. The Mean, Standard Deviation, and items' proportion

\begin{tabular}{|c|c|c|c|c|}
\hline No & Attributes & Item questions & Mean & SD \\
\hline 1 & Collaboration general & C1 - I enjoy collaborating with peers & 3.15 & 1.11 \\
\hline 2 & viewpoint & $\begin{array}{l}\mathrm{C} 2 \text { - Collaboration has positive impact on my } \\
\text { learning }\end{array}$ & 3.19 & 1.01 \\
\hline 3 & Collaboration satisfaction & $\begin{array}{l}\text { C3 - I am satisfied with most of my group } \\
\text { collaboration }\end{array}$ & 2.91 & 1.22 \\
\hline 4 & & $\begin{array}{l}\text { C4 - I am satisfied with most of the result of } \\
\text { my group collaboration }\end{array}$ & 3.10 & 1.21 \\
\hline 5 & Collaboration challenges & $\begin{array}{l}\text { C5 - Lack of coordination and conflict are } \\
\text { mostly influence my group collaboration }\end{array}$ & 3.01 & .93 \\
\hline 6 & & $\begin{array}{l}\text { C6 - Cultural differences in the team are the } \\
\text { barrier in my group collaboration }\end{array}$ & 2.67 & 1.01 \\
\hline 7 & e-collaboration & $\begin{array}{l}\text { C7 - The use of e-collaboration tools is hinder } \\
\text { the effectiveness of collaboration }\end{array}$ & 3.43 & 1.02 \\
\hline 8 & & $\begin{array}{l}\mathrm{C} 8 \text { - I prefer to have social interaction } \\
\text { compared to e-collaboration }\end{array}$ & 3.68 & 1.12 \\
\hline
\end{tabular}

From Table 2, the item that produced the average score furthest from the neutral response, 2.5, indicated the strongest opinion. Meanwhile, the item that closest to 2.5 performed the weakest. The result indicated that the students gave their strong endorsement to the item e-collaboration (C7 and C8). The participant perceived difficulties in the use of e-collaboration tools and they preferred to have social interaction. In general viewpoint, the perceived positive on the implementation of collaboration in class. In relation to collaboration satisfaction, the mean values suggest that the participants satisfied with their collaboration; however, the students' satisfaction on their group collaboration is lower than their satisfaction on the result of their collaboration. In addition, students consider lack of coordination seem to be the greater challenges compared to cultural differences.

\section{Open-ended questions and interviews \\ students' general perspective of learning through collaboration in group}

The open item in questionnaire asked participants to complete the question: "What makes a group considered as an effective collaboration?" after coding the response, the most mentioned themes was "having the good communication among its member" with 86 participants using terms alluding to this element. The second most common theme $(n=42)$ was "achieving the target of the group work"

In interview, students were asked to elucidate their answer on the questionnaire question. Many of the students highlighted the important of communication among the group members, one student stated:

Having a good communication with other members in the most important factor. Besides, I think work with person that understanding their job will be good. Each person is responsible for their respective share and then the results of their work will be put together. Although each person 
does their own part, it is done to achieve the same goal of the group; completing the assigned task. (Students A-interview)

Not only good in communication, Student B also mentioned about the role of self-regulated that might contribute to the effective collaborative in a group. Meanwhile, other students proposed of what so called good communication in a group is.

To have an effective group collaboration, every member of the group should have the ability in good communication. Because there is also some problems when members of group have different opinions and each member has a firm stand or stubborn. It is very hard, because it can lead to debates. (Student B-interview)

From Student A's point of view, he tried to express that who he worked with determined the effectiveness of group collaboration. Interestingly, some students also mentioned "working with the right person" as the factor in affecting collaboration. One students expressed:

My experience in a group work mostly bad. I was trying hard to make a discussion with my friends because they have so many reason when I ask them to discuss the material. So, I decided to work with some people in my group. I also asked the other friends to search the material but they did not collect it to me. That is really hard when we have collaboration with the wrong person. (Student C-interview)

Student $\mathrm{C}$ mentioned her difficulty in working with the wrong person because of team member were lack of responsibility in completing the target. Regarding to the barrier in online learning, one students shared their opinion:

Regardless the barrier of online learning setting, I think performed very well in a group. I amid that we lack collaboration and interaction in group discussion, instead of collaborating in completing our assignment, we only dividing the work that we should completed. However, considered this online learning situation, I think it is acceptable. (Students D-interview)

Student D statement indicated that the collaboration in online learning is more challenging than the collaboration in face-to-face learning. He/ she realized that his group were lack of interaction. Interestingly, one student asked to mention the strategy that provided by the lecturer to make students work collaboratively in online learning, she provided an example that involving group collaboration.

My lecturer often designed a debating activity in my synchronous class using Zoom application. She divided us into groups of three or four. Before starting the debate among group, she asked each member of the group to discuss on breakout room. And it was interesting activities. I like that idea since I can collaborate with my peers. (Student E-interview) 
EnJourMe (English Journal of Merdeka): Culture, Language, and Teaching of English

Vol. 6, No. 2, Desember 2021, pp. 152-162

Student E's account proved that to accommodate students' collaboration it is necessary to be creative to provide a meaningful learning experience in online learning class.

\section{The roles of students' learning experiences to promote students' collaboration}

It is necessary for teacher to promote students' contribution in variety of activities, such as MBKM program. In Faculty of ISIP, Merdeka University of Malang, a survey distributed to students, lecturer, and faculties relating to the implementation of MBKM program. Among all the students of Faculty of Social and Political Sciences $(n=1011), 86 \%$ completed the survey. Asked related to their understanding on this program, $70.24 \%$ of the total answer indicated that they understand about MBKM, and the rest of them (15.76\%) understand well. Meanwhile, 48 lecturers (100\%) joined this survey. The result revealed that $70.24 \%$ among them mentioned that they are understanding the policy of MBKM program.

Asked about how his collaboration experience in class contributed to his experience in joining MBKM program, one student explain:

My experience working in a group has made me understand how to create quality of teamwork, so I don't have any trouble working with the team during my internship. (Student F-interview)

As mentioned by Student F, he performed better because his experience in group work during his formal learning. And this statement supported by another student:

Mostly, the challenge is that how to deal with having a good communication with another group member. But my experience in class previously makes me understand how to deal when I am facing that situation. (Student G-interview)

Participant identified their personal experience in collaborative group contributed to the confidence in solving a problem. Besides, the participant responded positively on how group collaboration increased his communication skills.

\subsection{Discussion}

This study intended to explore high education students' experiences in group collaboration. The findings provide insights into the potential problems, challenges, and issues related to collaboration from the students' perspectives.

In the open question, the students mostly agree that communication is the main factor to have effective group collaboration. Linear to this idea, Head (2003) argued that collaboration is largely multi-dimensional; meaning that collaboration evolved variety of act of collaboration and from the following consequences of such activity. At the best level, collaboration incorporates quite a number carefully associated acts together with coordinating, consulting, communicating and cooperating. The result on students' questionnaire supported previous research that noted the importance of collaboration (Bedir, 2019; Rotherham \& Willingham, 2010; Soule \& Warrick, 2015). In addition, students perceived positively on their collaboration experiences. In Garrison and Arbaugh's (2007) 
community of inquiry framework, the perceptual level of collaborative learning is the level of social existence defined as the overall satisfaction of the online course and the psychological state of attachment and distance to the teacher. It turned out to be related to peer while learning online.

In addition, using NVivo software analysis, the result of open-ended questionnaire showed that most of students agreed that communication was the essential attribute for the effective group collaboration. In line to this, some studies attributed communication as a key to a group work success (see Ellis et al., 2021; Kerres \& Witt, 2003).

In answering the second research question, many studies also addressed some factors that promote groups' success, such as by designing course contents, activities, and communication (Kerres $\&$ Witt, 2003), and community consciousness among students (Rovai \& Jordan, 2004). It can be conclude that to promote an effective group work, it is necessary for the teacher to create learning experience that involve many strategies, for example online discussion (Wediyantoro et al., 2020). It is necessary to provide learning experience that booster students' engagement in collaborative work.

\section{Conclusion}

To conclude, the main aim of this research is to draw the students' experiences and satisfaction on collaborative learning. The result provides strong support that students perceived positively on the general viewpoint, satisfaction, challenges, and e-collaboration. In addition, the majority of the participants mentioned that to have an effective collaboration, communication among the group member should be involved. Meanwhile, the use of tools in e-collaboration task was the barrier of the effective collaboration. Drawing the result with the limitation of the study, it is expected for further analysis from lecturers' perspective on how they implement collaboration in their class.

\section{Acknowledgment and funding}

This research was funded by the Directorate General of Higher Education, Research and Technology (Ditjen Dikti Ristek) of the Ministry of Education, Culture, and Technology. Under MBKM Policy Research and Community Services Program based on Research Results and Prototypes for PTS (Perguruan Tinggi Swastal Private University).

\section{6. $\quad$ References}

Adams, P. (2006). Exploring social constructivism: Theories and practicalities. Education 3-13, 34(3), 243-257. https://doi.org/10.1080/03004270600898893

Al-Rahmi, W. M., \& Zeki, A. M. (2017). A model of using social media for collaborative learning to enhance learners' performance on learning. Journal of King Saud University-Computer and Information Sciences, 29(4), 526-535. https://doi.org/10.1016/j.jksuci.2016.09.002

Arifin, S., \& Muslim, M. (2020). Tantangan implementasi kebijakan "Merdeka Belajar, Kampus Merdeka" pada Perguruan Tinggi Islam Swasta di Indonesia. Jurnal Pendidikan Islam Al-Ilmi, 3(1). 
EnJourMe (English Journal of Merdeka): Culture, Language, and Teaching of English Vol. 6, No. 2, Desember 2021, pp. 152-162

Bedir, H. (2019). Pre-service ELT teachers' beliefs and perceptions on the 21st century learning and innovation skills (4Cs). Journal of Language and Linguistic Studies, 15(1), 231-246.

http://www.jlls.org/index.php/jlls/article/view/4/5

Bedwell, W. L., Wildman, J. L., DiazGranados, D., Salazar, M., Kramer, W. S., \& Salas, E. (2012). Collaboration at work: An integrative multilevel conceptualization. Human Resource Management Review, 22(2), 128-145. https://doi.org/10.1016/j.hrmr.2011.11.007

Braun, V., \& Clarke, V. (2006). Using thematic analysis in psychology. Qualitative Research in Psychology, 3(2), 77-101. https://doi.org/https://doi.org/10.1191/1478088706qp063oa

Creswell, J. W., \& Creswell, J. D. (2017). Research design: Qualitative, quantitative, and mixed methods approaches. Sage Publications.

Ellis, R., Bliuc, A. M., \& Han, F. (2021). Challenges in assessing the nature of effective collaboration in blended university courses. Australasian Journal of Educational Technology, 37(1), 1-14. https://doi.org/10.14742/ajet.5576

Gallant, M. H., Beaulieu, M. C., \& Carnevale, F. A. (2002). Partnership: an analysis of the concept within the nurse-client relationship. Journal of Advanced Nursing, 40(2), 149-157.

Garrison, D. R., \& Arbaugh, J. Ben. (2007). Researching the community of inquiry framework: Review, issues, and future directions. The Internet and Higher Education, 10(3), 157-172. https://doi.org/https://doi.org/10.1016/j.iheduc.2007.04.001

Head, G. (2003). Effective collaboration: Deep collaboration as an essential element of the learning process. Journal of Educational Enquiry, 4(2), 47-62.

Hein, G. E. (1991). Constructivist learning theory: The museum and the needs of people. A Paper Presented at the International Committee of Museum Educator's Conference Held Between15th22nd October in Jerusalem, Israel.

Henneman, E. A., Lee, J. L., \& Cohen, J. I. (1995). Collaboration: a concept analysis. Journal of Advanced Nursing, 21(1), 103-109.

Kerres, M., \& Witt, C. De. (2003). A didactical framework for the design of blended learning arrangements. Journal of Educational Media, 28(2-3), 101-113. https://doi.org/https://doi.org/10.1080/1358165032000165653

Krishnapatria, K. (2021). Merdeka Belajar-Kampus Merdeka (mbkm) curriculum in English studies program: Challenges and opportunities. ELT in Fokus, 4(1), 12-19. https://doi.org/10.35706/eltinfc.v4i1.5276

Lai, E. R. (2011). Collaboration: A literature review. Pearson Publisher. Retrieved November, 11, 2016

Lailiyah, M., \& Wediyantoro, P. L. (2021). Critical thinking in second language learning: Students' attitudes and beliefs. International Journal of Language Education, 5(3), 180-192. https://doi.org/10.26858/ijole.v5i3.18350

Longoria, R. A. (2005). Is inter-organizational collaboration always a good thing. J. Soc. \& Soc. Welfare, $32,123$.

Mondahl, M., \& Razmerita, L. (2014). Social media, collaboration and social learning - a case-study of Foreign Language Learning. The Electronic Journal of E-Learning, 12(4), 339-352. https://doi.org/10.7748/ns2012.09.27.3.31.p9397

Nehme, M. (2010). E-learning and Students ' Motivation. Legal Education Review, 20(1), 223-239. 
Assessing an effective collaboration in higher education: A study of students' experiences and challenges on group collaboration Malikhatul Lailiyah, Lian Agustina Setiyaningsih, Prilla Lukis Wediyantoro, Karlina Karadila Yustisia

Nguyen, T. T. L. (2019). Using ICT to foster collaborative writing for EFL university students in Vietnam. https://doi.org/10.1057/978-1-349-95988-4_335

Oh, J. E., Chan, Y. K., \& Kim, K. V. (2020). Social media and e-portfolios: Impacting design students' motivation through project-based learning. IAFOR Journal of Education, 8(3), 41-58.

https://doi.org/10.22492/ije.8.3.03

Razmerita, L., \& Kirchner, K. (2014). Social media collaboration in the classroom: A study of group collaboration. Lecture Notes in Computer Science (Including Subseries Lecture Notes in Artificial Intelligence and Lecture Notes in Bioinformatics), 8658 LNCS, 279-286.

https://doi.org/10.1007/978-3-319-10166-8_25

Rotherham, A. J., \& Willingham, D. T. (2010). "21st-century" skills. American Educator, 17(1), 17-20.

Rovai, A. P., \& Jordan, H. M. (2004). Blended learning and sense of community: A comparative analysis with traditional and fully online graduate courses. International Review of Research in Open and Distributed Learning, 5(2), 1-13.

Soule, H., \& Warrick, T. (2015). Defining 21st century readiness for all students: What we know and how to get there. Psychology of Aesthetics, Creativity, and the Arts, 9(2), 178-186.

http://0 - eds.a.ebscohost.com.librarycatalog.fresno.edu/eds/pdfviewer/ pdfviewer?vid=1\&sid=0952ae08-6f01-4c16-897d-94fdd7019518\%40sessionmgr4010

Tseng, H., Ku, H.-Y., Wang, C.-H., \& Sun, L. (2009). Key factors in online collaboration and their relationship to teamwork satisfaction. Quarterly Review of Distance Education, 10(2).

Van Boxtel, C., Van der Linden, J., \& Kanselaar, G. (2000). Collaborative learning tasks and the elaboration of conceptual knowledge. Learning and Instruction, 10(4), 311-330.

Wediyantoro, P. L., Lailiyah, M., \& Yustisia, K. K. (2020). Synchronous discussion in online learning: Investigating students ' critical thinking. EnJourMe (English Journal of Merdeka) : Culture, Language, and Teaching of English, 5(2), 196-203. https://doi.org/10.26905/enjourme.v5i2.5205 